\title{
Improving the Budgetary Process - Meeting the Public Where They Are
}

\author{
Marc Fudge*, PhD \\ Department of Public Administration, California State University San Bernardino, California, USA
}

*Corresponding author: Marc Fudge, PhD, Department of Public Administration California State University San Bernardino, California

Received Date: October 28, 2020

Published Date: November 30, 2020

\begin{abstract}
While it continues to be important for government to actively measure and improve the services they deliver to the public, it has also become increasingly apparent that more efforts need to be done to link performance measurement data with resource allocation decisions. The goals of this paper are two-fold; First, it aims to identify reasons for US municipalities to provide performance budgeting information online. The second goal is to make policy recommendations that are likely to facilitate greater public participation and engagement.
\end{abstract}

Keywords: Performance Budgeting, performance reporting, performance measurement, public participation

\section{Introduction}

Performance Budgeting may be seen as tool that affords public managers with additional information and greater context, to make resource allocation decisions. The manner in which government arrives at a position to implement a performance budgeting system is varied and can make take years before actual results are seen. As a result, there are many performance budgeting initiatives that fail, in part, because of poor goal setting, unrealistic expectations and an overall lack of planning. Despite challenges that may inhibit the implementation and sustainability of a successful performance budgeting system, there are four concepts and ideas that would likely increase success rates: transparency in the process to develop a performance budget; increasing the ability of the public to participate in the process; utilizing existing technologies in a manner that the public finds useful and benefical; and, demonstrating a higher degree of administrative effectiveness.

\section{From Performance Measurement to Performance Reporting}

Infusing the use of information and communication technologies to improve public-sector performance is occurring across all levels of government and reporting performance information online is a simple, yet important, way for government to communicate with the public. Fountain [1] says reporting results include communicating to elected officials and constituents a comprehensive set of clear, decipherable performance measures. "Reporting generally involves communicating the extent to which the governments' goals and objectives are being achieved with the information to assist users in assessing the efficiency and effectiveness of the program(s)" [1]. Hatry [2] states that reporting performance measures to external stakeholders allows the public, elected officials and interest groups to see what government is doing for them with the resources it is allocated. Essentially, performance reporting serves as an accountability mechanism for stakeholders to hold government to. External reporting may encourage the organization to perform better on the measures it reports. Further, comparisons made of similar reported measures allow one organization to measure or benchmark success against another. The Public Performance Measurement and Reporting Network (PPMRN) at Rutgers University-Newark, defines performance reporting as:

Summarizing information on an organization's performance results in comparison to the organization's previously stated targets. 
This information may be provided in comparison to previous year's performance, specific standards, or may be benchmarked across other performance efforts. Performance reports should be accessible to the reader and include key information such as the function of the organization, accomplishment in reaching targets, input and output measures, and helpful explanatory information. Public Performance Measurement and Reporting Network [3].

Measuring the performance of government is keenly viewed as more important now than perhaps at any other point in history. Why has the performance measurement trend emerged? Moreover, what does measuring organizational performance achieve? An established body of literature demonstrates how measurement can improve organizational performance [4-8]. As Epstein [9] notes, performance measures have three specific purposes: improve decision-making, improve service performance and improve public accountability. Kelly and Swindell [10] state that governments choose to utilize performance measures because their use reflects the genuine desire of public servants to find better ways to serve the public. Additionally, the use of performance measures demonstrates that government is not ineffective and unwieldy. Finally, they say, the application of scientific methods "promises to further professionalize the field of public administration" (p. 611).

The current emphasis on performance measurement is the result of the public demanding evidence of program and organizational effectiveness by government [11]. An essential reason to measure performance is to make program improvements that improve services to the public [2]. There is no one-size fits all performance measurement prescription for organizations to follow for success because performance measures can be used for multiple purposes.

\section{Linking Performance Management to Performance Budgeting}

As government attempts to improve service delivery, reporting performance budgeting information online has the potential to engage the public in the decision-making process, especially in terms of resource allocation. Previous research [12,13] has underlined the fundamental information government agencies try to achieve using performance budgeting which includes integrating performance measures into budgetary decision making. Further emphasizing the value of using performance information in the budgetary process Lu, Willoughby and Arnett [14] accentuate the importance of linking strategic plans with performance budgeting measures. Overall, financial reporting should provide easily accessible information that is easy for the public to comprehend. Performance Budgeting may be defined as a system where resource allocation decisions are made, in part, based upon the results and outcomes of program and department level goals.

Kelly and Rivenbark [15] soundly reject the idea that a fixed model to absolutely determine which programs are allocated resources, and which are not, be implemented. How can performance improvement be achieved if resources are taken away from programs that direly require them? Further, “...if programs and services popular among citizens were less successful than programs and services largely invisible to citizens, how can we achieve citizen accountability by redirecting resources away from them?" (p. 13). Kelly and Rivenbark (2011) propose the following as a useful definition of performance budgeting, "Performance budgeting is a budget development, implementation, and evaluation process that emphasizes performance management, allowing funding decisions to be based in part on the efficiency and effectiveness of service delivery" (p. 14). Their definition allows for public management discretion when allocating resources. It is exceptionally important for public managers, and government in general, to be afforded the opportunity to meet the public where they are and make resource allocation decisions accordingly.

\section{What Is Important to the Public?}

Overall, the public is most interested in government being held accountable for their actions, and in some cases, inaction. To achieve accountability however, it is multi-faceted process whereby performance measurement is the first step in the process towards achieving performance budgeting and accountability. Performance measures are also seen as an instrument that increases the accountability of public managers [2,16]. Poister [17] says performance measurement systems provide a tool for managers to utilize in an effort to maintain control over their organizations. Subsequently, internal and external stakeholders are also able to hold public organizations accountable to achieving the results they seek.

Overall, there are four key drivers influencing public accountability of government in terms of providing performance budgeting information: Transparency, public participation, Improved use of technology and administrative effectiveness.

\section{Transparency}

Measuring budgetary performance allows the public, public managers, elected officials, the media and other stakeholders to know that government is making every attempt to ensure it is doing what is necessary to meet their needs. When the public is included in the performance budgeting process, they view themselves as partners with government and a piece of the problem-solving solution. This can be achieved when performance budgeting information is made available to constituents online.

The implication a lack of transparency has is that government has less incentive to improve performance because there are fewer ramifications when it is unsuccessful or does not meet performance standards $[18,19]$. This occurs simply because less people are aware a problem may exist. A lack of transparency thus becomes a circular issue because not only are there fewer stakeholders to scrutinize issues because information is not available resulting in a decline of performance, but service delivery to the public is compromised. Ultimately, those who are affected the most severely 
are the residents of the jurisdiction. Government transparency and accountability can be addressed simply by providing performance budgeting information online. In failing to do so, it shows an overall lack of concern by the local government. Further, it demonstrates that the government does not highly value the views and opinions of its residents.

\section{Public Participation}

A common stream of research [20-22] has highlighted the growing importance of output legitimacy. According to Scharpf [23], the public increasingly judges the legitimacy of the public sector not only on the basis of input processes such as democratic elections, but also on the basis of public sector performance. Publicizing performance budgeting information online could increase the output legitimacy of the public sector [24]. According to Berman [25] "pervasive beliefs" that government officials, are corrupt, inept or take advantage of the public leads to a high degree of cynicism (p. 105). "Such disillusionment causes alienation and disengagement and is therefore a key interest to public administration and processes of democratic governance" (p. 105) Berman [25] found that municipalities use a variety of strategies to deal with a cynical public that are designed to improve trust and engagement with government. The strategies can fall into three broad categories: information, participation, and reputation. Also, in light of many cities recently emerging from a period of fiscal stress and economic uncertainty, increased public participation has occurred. According to Ebdon and Franklin [26] It seems as if now is an appropriate time for the public to play an important role to help government officials "determine the best solutions for government and the community" (p. 437). A critical element that will facilitate greater public participation with government is the utilization of performance budgeting. Performance budgeting may be viewed as a process whereby government provides resource allocation information on their websites thus allowing individuals an increased opportunity to engage with government. Bingham [27] state that "the new governance involves practices and processes for people to participate with government" (547). Jun \& Weare [28] assert that sharing power in decision-making and encouraging public autonomy and independence are activities sought in governance. Efforts to improve government engagement with the public that demonstrate governance have been increasing in recent years. Ultimately, performance budgeting is more likely to be used in local governments because it is easier to engage with the public as well as track performances and progress without interruptions and constraints [29].

\section{Better Use of Technology}

Research conducted by Pew Charitable Trusts [30] stresses the value of using data and evidence to support resource allocation decisions. Utilizing technology in this regard has never been more vital, especially as governments deal with the resultant effects of the COVID-19 pandemic. Further increasing the need for data-driven decision making is the fact that economies across world had finally emerged from the effects of the Great Recession and many economies had been ticking slightly upward prior to the global pandemic. Pew [30] suggests governments update budget guidelines, assess shortterm needs and program performance, and use clearinghouses to find missing information in an effort to become data-centric. This is another practical example where public managers can utilize the resources at their disposal to increase public participation with meaningful information, thus leading to better results. A question one may consider is why, with the advancement society has made using technology have governments not fully utilized all that is available to them to improve performance and services to the public? Failing to use technology that will inevitably improve government performance, enhance external communication to stakeholders, increase efficiency and reduce costs is perplexing.

As the public becomes more comfortable using various forms of technology, their expectation that businesses and government alike, also produce high-quality, user-friendly websites that provide a forum for engagement and interaction increases. Gone are the days when information could become dated and nobody would notice because currently users come in all shapes, sizes and demographics. With the increased number and type of users of information, also comes a higher number of actual interactions by a critical public. The Government Finance Officers Association (GFOA) has been setting guidelines and giving awards to local governments across the US who produce high-quality Popular Annual Financial Reports (PAFRs). One of the goals of PAFRs has been to provide budgetary and service-level performance reports to the public in an easily consumable manner. Additionally, the use of social media to afford the public an opportunity to communicate with government officials has steadily increased [31]. Yet, there continues to be missed opportunities for continued and sustained results [32].

\section{Administrative Effectiveness}

Today, public sector organizations do not solely rely upon output measures to determine effectiveness. How can an agency whose mission is to improve child care services to economically disadvantaged groups only measure performance based upon the number of cases cleared by a manager in a given month? Osborne and Gaebler [33] in their seminal book, Reinventing Government, conclude that entrepreneurial governments measure the performance of their agencies and focus on outcome measures and not output measures. Outcome measures refer to changes in communities or clients that are the result of a department or agency's activities and outputs [11]. Outcome measures are the primary goals or the major results an organization seeks to achieve and should be reflected in the strategic plan or mission statement. Hatry [2] defines outcomes as "events, occurrences, or conditions that are outside the activity or program itself and that are of direct importance to customers and the public 
generally" (p. 15). Charbonneau and Riccucci [34] state that performance measurement seeks to achieve results based upon a development of quantifiable indicators to track program achievement and outcomes. The primary focus of performance measurement is achieving results and it hinges on developing measurable indicators to track program performance and, ultimately, outcomes [35]. Implementing performance measures that focus on budgetary outcomes, and not just on outputs, have the potential to simultaneously improve efficiency and equity in the jurisdiction being served. The importance and overall goal of performance budgeting is not only to develop organizationspecific indicators to assess resource allocation decisions, but also to establish a system that can measure results of the indicators and use the information to improve management and democratic governance [36-40]. Managers that choose to adopt and implement a performance budgeting framework may do so for a variety of reasons. Poister [17] states that these initiatives are utilized by management for monitoring and reporting, strategic planning, financial management, program management and evaluation, contract management, benchmarking, communicating with the public and managing performance. Hatry [2] states the following as reasons why public managers choose to utilize performance data: formulating and justifying budget requests; making internal resource-allocation decisions; examining in-depth performance issues; motivating personnel to make program improvements; formulating and monitoring contracts to grantees; supporting strategic planning; evaluating programs; communicating with the public to improve trust; and to provide improved services more efficiently. Behn [41] suggests that managers should identify the purposes of using performance measures by asking questions. For example, managers should ask "on what programs, people, or projects should my agency spend the public's money?" (p. 588).

\section{Policy Implications}

As the service delivery responsibility of local government continues to grow, so do the demands of the public. Increasingly, the public seeks effective and efficient provision of services [4]. Online performance budgeting is an effective method for government to demonstrate what it is actually doing with the resources allocated to them, thus simultaneously improving accountability. Another implication of this paper on government performance is the effective utilization of performance budgeting information. A question many have regarding the collection of performance data is, "What will happen with the large amount of information produced by these management systems?" A common managerial response cited is that their city collects an inordinate amount of information but that it is not all used. This seems to beg the question, "Why collect this information in the first place?" When performance budgeting data is utilized to inform decision-makers, then they are not simply measuring performance but managing performance. Specifically, when performance budgeting data is used effectively, they may serve as a manner to assist the agency or program achieve governmental performance goals. A final implication of performance budgeting stems from the fact that they provide a method to track resource allocation and actually help monitor costs better. A common barrier to any performance measurement system or performance budgeting initiative, is the initial outlay of cost during implementation. Although these costs can be substantial, future costs savings as a result typically outweigh what is required at the onset. Ultimately, performance budgeting efforts are likely to place jurisdiction in a better position to withstand fiscal crises.

\section{Conclusion}

This study has attempted to integrate the fields of performance measurement and performance budgeting through an accountability framework built on transparency, public participation, improved use of technology, and effectiveness. Intuitively, examining accountability from this framework appears to be a mutually beneficial relationship especially when one considers that performance budgeting is geared toward informing the public of what government is doing with the resources it is allocated. Coupled with the frenetic pace information technology is being utilized by government and the public alike, this merger is bound to occur with greater frequency in the near future. Based upon political and socioeconomic factors, the public is as interested as ever in consuming meaningful government performancerelated information. What is missing in some jurisdictions is the ability of many governments to decide how exactly to increase public participation to facilitate worthwhile feedback and thought. If performance data is going to be used as a management tool to enhance the administrative capabilities of government and improve service delivery, then government must become more receptive to relying on public feedback. Improving performance budgeting information along with the ability to access it will likely increase participation and assist government in meeting the public where they are.

\section{Conflict of Interest}

No conflict of interest.

\section{Acknowledgement}

None.

\section{References}

1. Fountain J, Campbell W, Patton T, Epstein P, Cohn M (2003) Reporting performance information: Suggested criteria for effective communication. Governmental Accounting Standards Board, Washington, D.C, USA, pp. 205.

2. Hatry H (2006) Performance measurement-Getting results. The Urban Institute Press, Washington, D.C, USA.

3. Public Performance Measurement and Reporting Network (PPMRN) (2008) Key terms.

4. Ammons D (2007) Performance measurement: A tool for accountability and performance improvement. County and Municipal Government in North Carolina 16: 1-12.

5. Ho A (2007) GPRA after a decade: Lessons from the government performance and results act and related federal reforms. Public Performance Management Review 30(3): 307-311. 
6. De Lancer Julnes P (2006) The utilization of performance measurement information. In: Holzer, M, Lee, S (Eds.), Public productivity handbook, ( $2^{\text {nd }}$ edn), Marcel Dekker, Inc., New York, pp. 285-296.

7. Berman B (2008) Involving the public in measuring and reporting local government performance. National Civic Review, Spring, p. 3-10.

8. Kennerly M, Neely A (2002) A framework of the factors affecting the evolution of performance measurement systems. International Journal of Operations and Production Management 22(11): 1222-1245.

9. Epstein P (1984) Using performance measurement in local government New York: Van Nostrand Reinhold, Co.

10. Kelly J, Swindell D (2002) A multiple-indicator approach to municipal service evaluation: Correlating performance measurement and citizen satisfaction across jurisdictions. Public Administration Review 62(5): 610-621.

11. Wholey J, Hatry H, Newcomer K (2004) Handbook of practical program evaluation. ( $2^{\text {nd }}$ edn), Jossey-Bass, San Francisco, USA.

12. Melkers J, Willoughby K (2005) Models of performance-measurement use in local governments: Understanding budgeting, communication, and lasting effects. Public Administration Review 65(2): 180-190.

13. Ho A (2002) Re-inventing local governments and the e-government initiative. Public Administration Review 62(4): 434-444.

14. Lu Y, Willoughby K, Arnett S (2011) Performance budgeting in the American states: What's law got to do with it? State \& Local Government Review 43(2): 79-94.

15. Kelly J, Rivenbark W (2011) Performance Budgeting for State and Loca Government ( $2^{\text {nd }}$ edn), ME Press, New York.

16. Lu Y (2007) Performance budgeting: The perspective of state agencies Public Budgeting and Finance, Winter, p. 1-17.

17. Poister $\mathrm{T}$ (2003) Measuring performance in public and nonprofit organizations. Jossey-Bass, San Francisco, CA.

18. Ruijer HJM (Erna) (2017) Proactive transparency in the United States and the Nether- lands: The role of government communication officials. American Review of Public Administration 47(3): 354-375.

19. Hibbing JR, Theiss-Moore E (2001) Stealth democracy: Americans' beliefs about how government should work. Cambridge, Cambridge University Press, UK.

20. Lu Y (2011) Individual engagement to collective participation: The dynamics of participation pattern in performance budgeting. Public Budgeting \& Finance 31(2): 79-98.

21. Halachmi A, Holzer M (2010) Citizen participation and performance measurement: Operationalizing democracy through better accountability. Public Administration Quarterly 34(3): 378-399.

22. Van Ryzin G (2006) Testing the expectancy disconfirmation model of citizen satisfaction with local government. Journal of Public Administration and Research Theory 16(4): 599-611.

23. Scharpf F (1999) Governing in Europe: Effective and democratic? Oxford University Press, Oxford, England.

24. Meijer A (2007) Publishing public performance results on the Internet-Do stakeholders use the Internet to hold Dutch public service organizations to account? Government Information Quarterly 24: 165185.
25. Berman E (1997) Dealing with cynical citizens, Public Administration Review 57(2): 105 -112.

26. Ebdon C, Franklin A (2006) Citizen participation in budgeting theory. Public Administration Review 66(3): 437-447.

27. Bingham L, Nabatchi T, O'Leary R (2005) The new governance: Practices and processes for stakeholder and citizen participation in the work of government. Public Administration Review 65(5): 547-558.

28. Jun K, Weare C (2010) Institutional motivations in the adoption of innovations: The case of e-government. Journal of Public Administration Research and Theory, p. 1-25.

29. Hou Y, Lundsford R, Sides K, Jones K (2011) State Performance-Based Budgetingin Boom and Bust Years: An Analytical Framework and Survey of the States, Public Administration Review 71(3): 370-388.

30. Pew Charitable Trusts (2020) How Public Officials Can Use Data and Evidence to Make Strategic Budget Cuts. Research Brief.

31. Fudge M (2014) Enhancing user engagement with elected officialsContextual predictors influencing the use of social network applications on municipal web sites. International Journal of Technology Diffusion 5(3): 1-21.

32. Fudge M, Sirotnik B, Bockman S (2014) Missed opportunities: Improving deliberation through digital democracy. International Journal of e-Governance and Networks 2(1): 65-85.

33. Osborne D, Gaebler T (1992) Reinventing government-How the entrepreneurial spirit is transforming the public sector. Addison-Wesley, New York.

34. Charbonneau E, Riccucci N (2008) Beyond the usual suspects-An analysis of the performance measurement literature on social equity indicators in policing. Public Performance and Management Review 31(4): 604-620.

35. Callahan K (2007) Elements of effective governance-Measurement, accountability and participation. CRC Press, New York.

36. Yang K, Hsieh J (2007) Managerial effectiveness of government performance measurement. Public Administration Review, pp. 861-879.

37. Moynihan D, Ingraham P (2006) Integrative leadership in the public sector: A model of performance-information use. Administration and Society 36(4): 427-453.

38. Ho A (2005) Accounting for the value of performance measurement from the perspective of Midwestern mayors. Journal of Public Administration Research \& Theory 16: 217-237.

39. Hatry H (2002) Performance measurement: Fashions and fallacies. Public Performance and Management Review 25(4): 352-358.

40. Wholey J (1999) Performance-Based management: Responding to the challenges. Public Productivity and Management Review 22(3): 288307.

41. Behn R (2003) Why measure performance? Different purposes require different measures. Public Administration Review 63(5): 586-606. 